\title{
Az új városi urbanizációs modell szocialista és/vagy globális természete
}

\author{
The socialist and/or global nature of the new town \\ urbanization model
}

\author{
SZIRMAI VIKTÓRIA
}

SZIRMAI Viktória: kutatóprofesszor, MTA TK Szociológiai Intézet; 1097 Budapest, Tóth Kálmán u. 4.; tanszékvezető, egyetemi tanár, Kodolányi János Főiskola; 1139 Budapest, Frangepán u. 50-56.; szirmai.viktoria@tk.mta.hu

KULCSSZAVAK: szocialista urbanizáció; globális urbanizáció; új városok társadalmi-gazdasági polarizációja; új városok térbeli társadalmi szerkezete; európai városfejlődési trendek

ABSZTRAKT: A tanulmány a magyarországi ún. szocialista új városi térségek mai átalakulásait, a történeti hatások, az ún. szocialista urbanizáció jelenkori érvényesüléseit, valamint a globális urbanizáció megnyilvánulásait mutatja be. Az új várostérségi társadalmak térbeli elhelyezkedésének empirikus feltárásával az európai, egyben a globális városfejlődési trendekhez történő közeledés, a konvergencia, illetve divergencia jelenségeit, közte az új városi jelleg mai relevanciáit is elemzi. Az empirikus vizsgálatok szerint a posztszocialista új városok és azok térségei korántsem jelentenek homogén közeget: a gazdasági és a szociológiai jellemzőik, társadalmi összetételük és térbeli elhelyezkedésük sajátosságai alapján különböző fejlettségi csoportegységekből állnak. A gazdaságilag és társadalmilag fejlettebb jellemzőkkel rendelkező új városi csoportok sokkal inkább alkalmazkodnak a globális világhoz, esetükben jellemzőbb a nyugat-európai trendekhez történő közeledés, mint a fejlettségük szerint visszamaradottabb új várostérségi csoportok esetében, ahol erőteljesebben érvényesülnek a történeti hatások, és ahol tapasztalhatóak a divergencia jelenségei is.

Viktória SZIRMAI: research professor, Institute for Sociology, Centre for Social Sciences, Hungarian Academy of Sciences; Tóth Kálmán u. 4., H-1097 Budapest, Hungary; professor, head of department, Kodolányi János University of Applied Sciences; Frangepán u. 50-56., H-1139 Budapest, Hungary; szirmai.viktoria@tk.mta.hu

KEYWORDS: socialist urbanization; global urbanization; societal and economic polarization of new towns; spatial-social structures of new towns; European urbanization trends

ABSTRACT: The study presents the recent transformations of Hungarian "new" (i.e. socialist) town regions by analyzing manifestations of historical impacts, specifically, "socialist" and global urbanization effects. Based on the spatial distribution (or position) analysis of new town societies, the article demonstrates their diverging and converging aspects from and to European and global urbanization trends. In addition, the study also provides comments on the current

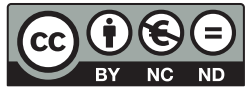


relevancy of the historically established new town characteristics. The empirical findings verified the diversification of Hungarian new town regions: they include various development units based on their various economic and sociological characteristics, for instance, their social structural and spatial distribution features. The most advanced town groups adapt more significantly to the global and, particularly, the Western European world than the underdeveloped ones, where the historical diverging effects manifest more spectacularly.

\section{Az európai új városok problematikája}

Kelet- és Közép-Európában, közte Magyarországon sem épülnek már új városok: nem tapasztalni sem tudományos, sem pedig közpolitikai érdeklődést a posztszocialista új városok - sem a múltbeli, sem pedig a mai - jelenségei iránt. Az érdektelenség mögött a szocialista rezsimek lebomlásának folyamatát, a múlttal, közte a szocialista viszonyok egyik várostípusával való leszámolás társadalmi, közpolitikai igényeit látni, továbbá a különböző várostípus-pozíciók hierarchikus átrendeződésének sokszor ki nem mondott szempontjait, azok társadalmi közérdeklődést kiváltó következményeit, jelen esetben inkább annak hiányát is. Az 1989-1990-es társadalmi politikai rendszerváltás nagyon sújtotta ezeket a településeket: miközben számos település jól kezelte a válságait és sikeres gazdasági szerkezetváltást valósított meg, a szocializmusból örökölt új városok inkább a vesztesek közé kerültek. Bár később kiderült, nem mindegyikük.

Az európai új városok a kialakításuk időszakában nem csupán kiemelt figyelmet és fejlődési lehetőségeket, állami és piaci támogatásokat kaptak (nem egyszer a többi település rovására), hanem sajátos missziókkal is rendelkeztek. Az első tervezők, így akár Ebenezer Howard, Le Corbusier vagy a szovjet konstruktivisták, a CIAM-csoport (Comité Internationale pour la Resolution des Problemes de l'Architecture Contemporaine) vázlataiban az új városok fejlesztési céljai a városrobbanás időszakára (amely az urbanizáció első szakasza) jellemző társadalmi problémák, feszültségek és a szegénység térbeli megoldásaiként jelentek meg (Le Corbusier 1923; Howard 1898).

Az első új városi tervekhez kapcsolt társadalmi, gazdasági és területformálási koncepciók tárgyiasult formákat is kaptak, hiszen a 2. világháború után egész Európában (közte kiemelten az Egyesült Királyságban, Skandináviában, de az Egyesült Államokban is) számos új város épült. Miközben nyilvánvaló, hogy az urbanisztikai elméletek soha nem realizálódtak volna, ha a 2. világháborút követően nem alakulnak ki az új városok építését igénylő társadalmi szükségletek. Mindenekelőtt azokról a nyugat-európai központi kormányzati érdekekről van szó, amelyek az új városi tervek megvalósításától, az új városok építésétől várták a gazdaság területi fejlődését, egyes társadalmi feszültségek kezelését, közte a korabeli tömeges lakáshiány felszámolását, de az életmód alakítását is. A kelet- és közép-európai országok a szocialista típusú egyszerű tőkefelhalmozást, az erőltetett nehézipari fejlesztési programok megvalósítását 
és az ún. szocialista urbanizációs modell, vagyis - a nyugati világban kibontakozott területi fejlődési folyamatoktól teljesen eltérő - közösségi, egyenlőtlenségek nélküli városmodell megteremtését is várták.

Az európai új városok építésének lendülete az 1970-es évek végén, az 1980-as években megtört a kitűzött célok sikertelensége következtében, amit az 1970-es években kirobbant gazdasági válság, a korabeli demográfiai hullámok miatt lecsökkent új városi népességszám, valamint az a tény okozott, hogy a nagyvárosi térségi fejlődés szabályozása kudarcot vallott. A kelet- és közép európai új városokat egyéb okok miatt bélyegezték sikertelennek: a kommunista rendszerek folyamatosan éleződő válságai miatt az új városok egyre inkább vesztettek ideologikus varázsukból, szertefoszlottak a kialakításuk idején megfogalmazott utópista vágyálmok, az akkor hatalmon lévők által tudatosan hirdetett, manipulatív remények, hogy itt élni jobb, mint más városokban, mert az élet közösségibb, boldogabb. Az ott élők tapasztalataiból, de a korabeli kutatásokból is kiderült, hogy az új városi létformák sem jobbak, mint az egyéb városi létformák (Mód, Kozák 1974). Az új városok leminősítésének (fóként a magyar esetben) fö oka mégsem ez volt, hanem az, hogy időközben megváltozott a városok közötti forrásmegosztás: a központi hatalommal szemben a megyeszékhelyek, a nagyvárosok több fejlesztési forrást vívtak ki maguknak az új városok rovására is. Az új elosztás legitimálására megfelelő érvnek tűnt az újvárostervezés bukásának hangsúlyozása.

A 2000-es évek azonban meghozták a nyugat-európai új városok rehabilitációját: a korabeli kutatások a korábbiakhoz képest differenciáltabb válaszokat adtak, az új városok beharangozott csődje nem minden esetben következett be (Haumont et al. 1999). Ma már számos fejlett nyugat-európai és fejlődő országban is egyre népszerúbbek az újváros-fejlesztési célok és stratégiák. Sok helyen tünik fel újra az a városfejlesztési törekvés, amely a tervezés eszközeivel, köztük új települések kialakításával kíván a területi társadalmi folyamatokba beavatkozni. Például az angol újváros-fejlesztési modellek modern változatai jönnek létre Ázsiában, Kínában (közte Hongkongban is), ahol a globális urbanizáció itt kibontakozó első szakaszának, a városrobbanás feszültségei kezelésének kiemelt tervezési eszköze az új városok építése, fejlesztése. Noha az európai, de főként a harmadik világbeli új városok között igen nagyok a fejlettség szerinti eltérések, a francia új városok némelyike szintén a reneszánszát éli, a nagyvárosi terjeszkedés, a globális urbanizáció második fázisának szabályozásában komoly szerepet tölt be (Brevet 2011). Az International New Town Institute 2010-ben megrendezett nemzetközi konferenciáján elhangzottak szerint az új városok világszerte átalakulnak, megújulnak, modernizálódnak, a mai lakossági igényekhez igazodó urbanisztikai és társadalmi arculatot, valamint új nevet is kapnak: új városok, vagy másképp a „tervezett” városok helyett „,nem tervezett" városokként hívják őket (Provoost 2010).

Kelet-és Közép-Európában a városi népesség 2-5\%-a él új városokban, Magyarországon a városi népesség 4,6 \%-a (www.tradingeconomics.com). A poszt- 
szocialista országokban az új városok száma megközelíti az 1200-at, ezek túlnyomó többsége, $\mathrm{kb} .1000$ város a volt Szovjetunió területén jött létre (Uzzoli 2013, 35.). E városok helyzetéről nincs átfogó tudományos képünk, pedig fontos lenne megtudnunk, mi történik ezekben a városokban, milyen társadalmi problémák, konfliktusok jöttek létre a 20. század végén, a 21. század elején, következésképpen milyen releváns társadalmi beavatkozási, problémakezelési eszközök kialakítására lenne szükség.

Az új városok mai átalakulási folyamataival kapcsolatos tudás segítséget nyújthatna a kelet- és közép-európai, vagy másképp a szocialista urbanizációs modell mai természetének megítélésében is. Enyedi György szerint ezt nem a „történelmi érdekesség” kedvéért kell feltárni, hanem azért, hogy kiderítsük „az európai kontinens városrendszerének integrálódását, a Nyugat és a Kelet városfejlődési folyamatainak közeledési trendjeit" (Enyedi 2012, 147.). A keletés közép-európai urbanizációs modell természetéről már hosszú ideje folynak tudományos viták, ennek két markáns, egyben eltérő álláspontját Szelényi Iván és Enyedi György nézetei képviselik a legtisztábban (Enyedi 1996, 2012; Szelényi 1996). Szelényi állítása szerint ,a kelet-európai szocialista városfejlődés meglehetősen különbözik a hasonló gazdasági fejlettségi szinten lévő nyugat-európai országok városfejlődésétől” (Szelényi 1996, 286.). Enyedi szerint azonban „a szocialista urbanizáció (pontosabban a kelet- és közép-európai országok urbanizációja) nem képez új globális urbanizációs modellt, mivel inkább arról van szó, hogy a városfejlődés globális szakaszai a kelet- és közép-európai szocialista országokban követő jelleggel megismételődnek, mégpedig a késleltetett gazdasági és városfejődési modernizáció, illetve a szocialista politikai rendszer mechanizmusai okán” (Enyedi 1996, 102.). Ezt bizonyítja, hogy az „1970-es évektől a szocialista országok urbanizációs folyamatai egyre több hasonlóságot mutattak a nyugat-európai folyamatokkal" (Enyedi 1996, 147.). Musil lényegében hasonló véleményen van, miközben rámutat a folyamat történeti differenciáltságára: „a szocialista országokban érvényesülő urbanizációs pályák különböznek a kapitalista országokétól, főként a szocialista hatalom átvétel első szakaszában. De 10 vagy 15 szocialista év után a kelet- és a közép-európai urbanizációs trendek közelítenek a nyugat-európaihoz" (Musil 2005, 40.).

Én magam is ezt a felfogást képviselem. Hiszen Kelet-Európa, illetve Keletés Közép- Európa településeit, városait már a globalizált urbanizáció folyamatai alakítják. ${ }^{1}$ Ez a mai világ új globális gazdasági mechanizmusait, a kapitalizmus világrendszerének teljes kibontakozását, illetve az abból is fakadó területi folyamatokat, regionális konfliktusokat, éles társadalmi egyenlőtlenségeket fejezi ki (Enyedi 2012). A globális területi világrend azonban nem egyszerre épül ki, egymás mellett érvényesülnek a különböző urbanizációs ciklusok, de a történetileg szerveződött, jóllehet már megszűnőben lévő szocialista világrendszer hatásai szintén hosszú ideig megnyilvánulnak, visszarendeződések is történnek.

Véleményem szerint a kelet- és közép-európai, közte a magyar új városok elemzése nemcsak arra ad módot, hogy megvizsgáljuk, mi történik ma a vala- 
mikor szocialistának nevezett új városok társadalmaiban. Hanem arra is lehetöséget kapunk, hogy értelmezzük a szocialista urbanizáció mai tartalmát, megnézzük a szocialista vonások átalakulását, leépülését, a szocialista és a mai (maradjunk ennél a kategóriánál) kapitalista vagy globális urbanizációs vonások szervesüléseit.

Kétség sem férhet ahhoz, hogy ezek a városok a szocialista urbanizáció prototípusai voltak. Kialakulásukat egyértelmüen a szocialista rendszerek viszonyai, ennek keretében az állami tulajdon túlsúlya, az önkormányzatiság hiánya, a bürokratikus kapcsolati rendszerek határozták meg (Kornai koncepciója alapján lásd Barta 2014, 75.). Az újvárosfejlődés korai szakaszaiban speciális jellemzőkkel is rendelkeztek: mégpedig az országos redisztributív társadalomirányítási mechanizmusokban, a térség- és településfejlesztési gyakorlatokban kiemelt pozíciókkal, a többi településhez képest (az 1970-es évekig) jóval több állami lakásfejlesztési forrással. Továbbá monolitikus, főként nehézipari gazdasági szerkezettel, az állami nagyvállalatok túlzott hatalmával, az egysíkú, alapvetően a szocialista realista építészeti stílus és tervezési elvek szerinti lakótelep-építkezések, később a házgyári paneltechnológiára alapozott lakótelepi épületek túlsúlyával. És viszonylag homogén társadalmi, foglalkozási összetétellel is, a munkásrétegek, a férfiak, a fiatalok magas arányaival, a városi polgárság hiányával, a vidékről - szinte állami kényszerekre és a vidéki munkaalkalom hiánya miatt - ide vándorolt, szakképzetlen, gyökértelen, individualizált népességgel, kiknek területi elhelyezkedését a központi lakáselosztási mechanizmusok döntötték el.

Ezeket a jellemzőket ilyen tiszta formában ma már nem találjuk meg; már a szocialista érában elkezdődött a leépülésük, a társadalmi, politikai rendszerváltás pedig további átalakulásokat okozott. Ezek a városok mégis itt vannak, és talán többet őriztek meg a történelmi múltjukból, mint gondolnánk. Ez akkor is így van, ha sokan (köztük nem is az új városokat, hanem a városokat kutatók) azt állítják: ma már nem lehet ezekről mint új városokról beszélni, nincsenek speciális sajátosságaik, mivel teljes mértékben integrálódtak, beleolvadtak a többi település rendszereibe, ma már olyanok, mint a többi város. Én azonban a friss kutatásaink alapján azt gondolom, hogy az átalakulásuk még nem fejeződött be; a konvergencia, tehát a többi városhoz való közeledés mellett még mindig érzékelhetőek a divergenciák, a különbségek is.

Ebben a tanulmányban ezt az átalakulást kizárólag két tényező alapján mutatom be. Mégpedig alapvetően saját kutatásaink alapján elemzem egyrészt az új városok közötti különböző típusú polarizációkat, másrészt a térbeli, társadalmi, szerkezeti sajátosságokat. Az új városi tematikát két különböző időszakban, OTKA támogatású újvároskutatás keretében vizsgáltam, számos munkatársammal együtt. Az első kutatás 2010 és 2012 között valósult meg (Szirmai 2013). ${ }^{2}$ A másik kutatást 2013 és 2016 között végeztük (az eredményekről lásd: Szirmai 2016). A Társadalmi polarizáció a kelet-és közép-európai új városi térségekben: a rendszerváltás és a globalizáció hatásai címü projekt 
épített az előző kutatás eredményeire, és más kelet- és közép-európai elemzések alapján, számos szempontból tovább is lépett, a magyar viszonyok mellett a lengyel és a szlovák folyamatokat is feltárta. ${ }^{3}$ Ebben a projektben, különböző esettanulmányok mellett, 11 új magyar város reprezentatív szociológiai vizsgálatára is sor került. ${ }^{4} \mathrm{Az}$ új városi polarizációs viszonyok egzaktabb megismerése érdekében összehasonlító elemzések készültek: erre két nagyvárostérségi reprezentatív szociológiai felvétel adatai adtak lehetőséget, ezek bemutatásra a terjedelmi korlátok miatt itt nincs mód (Csizmady, Ferencz 2016; Szirmai 2009; Szirmai, Ferencz 2015). ${ }^{5}$

\section{Társadalmi-gazdasági polarizáció a magyar új városok között}

A globális urbanizáció a fejlett centrumországokból (a globális városokból, a nagyvárosokból, a fơvárosokból) indul ki, terjed tovább az egész világon, eközben eltérő módon és mértékben érinti a különböző országokat, perifériákat, azok településeit. Dinamikus gazdasági és társadalmi fejlődést generál, valamint súlyos térbeli társadalmi egyenlőtlenségeket okoz, különösképpen akkor, ha a fogadó felek, országok nemzeti, regionális, helyi adottságai fejletlenek, ha felkészületlenek a modernizációs folyamatok befogadására, illetve annak aktív alakítására.

Véleményem szerint az új városok mai pozíciói hasonló folyamatokban alakulnak: a történetileg kialakult szocialista vonásaik aszerint változnak, tűnnek el vagy alakulnak át, hogy a vizsgált települések milyen helyet foglalnak el a globális urbanizációt mozgató gazdasági és térbeli társadalmi erőterekben. Milyen globális gazdasági és egyéb társadalmi hatások érik őket, egyáltalán érik-e őket ilyen hatások? Elkerülik-e ezeket a városokat a globális folyamatok, akár a helyi fogadókészség hiányában, akár a helyi viszonyok felkészületlensége okán? Ezekben az esetekben a korábbi történeti modellek viszonyai között maradnak a városok, ahol vagy stagnálnak, vagy egyre lejjebb csúsznak, periferikus helyzetekbe kerülnek, ahogy ez a globális városrendszerekben történik. Ezekre a kérdésekre adott válaszok, vagyis a globális hatások és a történeti kondicionáltságok (a nemzeti és helyi gazdaságok specifikus jellemzői, a gazdasági szerkezetváltások dinamikái, a társadalmi jellemzők) metszetei adják az újvárosviszonyok mai szerveződéseit.

A globális gazdasági hatások a kelet- és közép-európai térséget, közte Magyarország minden települését differenciáltan érintették. Köztudott, hogy a fövárosi és a nyugat-magyarországi térségek jóval több külföldi tőkebefektetéshez jutottak, mint a kelet-magyarországi térségek és azok városai. Mindezek hatására a szocialista időszakból megmaradt térbeli és társadalmi egyenlőtlenségek, a városhálózati differenciáltságok tovább éleződtek, amelyeket még tovább erősítették 1989-1990 átmenetének folyamatai is: így a piaci viszonyok (közte a lakás- és az ingatlanpiac) kialakulása és annak addig nem ismert köve- 
telményei, az önkormányzatok önállósága, de egyben a fejlesztési forrásaik szűkössége, a privatizációs mechanizmusok feszültségei. A globális hatások és a rendszerváltó mechanizmusok kedvezőtlen következményeiként a különböző régiók és városok közötti gazdasági és társadalmi szakadékok nemcsak nőttek, hanem új megjelenési formákat is kaptak (Barta 2002; Enyedi 1996; Horváth, Rechnitzer 2000; Izsák 2003; Nemes Nagy 2005; Rechnitzer 2002).

A kedvezőtlen körülmények az újvárostérségek esetében fokozottabb mértékben mutatkoztak meg. Többnyire kedvezőtlen regionális adottságaik mellett egyéb gazdasági és társadalmi nehézségek is sújtották őket: számottevő adósságállomány, a keleti piacok elvesztése, a veszteséges termelés és a korszerütlen termék- és árszerkezet, komoly környezetvédelmi károk, az állam szinte folyamatosan változó (hol támogató, hol akadályozó) érdekei, elenyésző külföldi müködő tőke és szintén jelentéktelen nemzeti, illetve helyi befektetői szándékok (akadályozva az állami nagyvállalatok privatizációit). Mindez nagyon hamar a nagyipari cégek összeomlásához, ebből adódóan komoly mértékü munkanélküliséghez is vezetett. A statisztikai adatok szerint az új városi foglalkoztattak száma 2001-re 22\%-kal esett vissza (Csizmady 2013, 225.). A többnyire ipari foglalkoztatottak a hiányzó vagy gyenge szolgáltató szektor miatt kevésbé tudtak elhelyezkedni. A 11 új városra kiterjedő reprezentatív kutatásunk idején, 2015-ben, a munkanélküliség átlagos szintje 9,5\% volt, ami jóval meghaladta az országos átlagot (6,1\%). A probléma súlyosságát jelzi, hogy az általunk megkérdezett újvárostérségekben élők felét már érintette korábban is a munkanélküliség. Magas volt azok aránya is, akik (noha különböző mértékben, de) nehéz anyagi körülmények között éltek: a megkérdezettek csupán közel fele állította, hogy jól kijönnek a jövedelmükből, a másik fele vagy nélkülözött, vagy napról napra élt. A családoknak csak 5\%-a válaszolta, hogy nincsenek gondjai. Magas volt a hitellel rendelkezők aránya is. Azt tapasztaltuk, hogy az új városok esetében a legalacsonyabb jövedelmü háztartások aránya majdnem kétszeresen haladta meg a nagyvárosi térségekben élőkét (Ferencz 2015).

Vizsgálataink szerint az átalakulási folyamatok nemcsak nehezen, hanem az új városok között nagy különbségekben, erősen polarizált módon mentek végbe. Az átalakulások feltárására többféle megközelítési módot is alkalmaztunk: ezek releváns dimenziók, illetve mutatók alapján rangsorolták, tipizálták az új városok mai helyzetét. Az OTKA-kutatásban mindenekelőtt különböző társadalomstatisztikai mutatók figyelembevételével rangsoroltuk a városokat: a népességszám, a vándorlási egyenleg, az öregedési index, a lakásviszonyok, a fizikai és a szellemi foglalkozásúak arányai, a munkanélküliség és az iskolai végzettség szerint. Ezek eredményeként a magyar új városok között három különböző fejlettségü térségcsoport bontakozott ki (Csizmady 2013). Egyrészt egy fejlett új városi csoport: Százhalombatta, Paks, Tiszaújváros, Tatabánya. Ezekben a térségekben a válság korántsem volt olyan éles, mint máshol: kedvező helyi adottságaik, például az állam számára fontos gazdasági (és politikai) funkcióik, és az ebből is adódó állami támogatások segítségével, 
vagy éppen a jó földrajzi elhelyezkedésük és közlekedési pozícióik, valamint a külföldi működő tőke beruházásai révén (köszönhetően a gyors privatizációs folyamatoknak is) könnyebben alkalmazkodtak a piaci követelményekhez. Ennek következtében itt a munkanélküliek aránya átlag alatti volt, a vándorlási egyenleg pedig pozitívnak bizonyult. Ebben a folyamatban a helyi társadalmi sajátosságok - főleg az iskolázott és szakképzett munkaerő - is segítették ezeket a városokat. A második csoportot a stagnálók alkották: Ajka, Dunaújváros, Oroszlány és Várpalota. Ezek a városi térségek a válságot alapvetően kezelni tudták, a népességüket többé-kevésbé meg tudták őrizni, a lakosság iskolai végzettsége viszonylag kedvező. A továbblépés irányai és föként forrásai azonban bizonytalanoknak tűntek, főként erős (világ)gazdasági kiszolgáltatottságuk, illetve a korábbi gazdasági szerkezetváltás lassúsága miatt. A statisztikai adatelemzéseink szerint a harmadik csoportot a rendszerváltás valóban vesztesei adják: Kazincbarcika, Komló és Ózd. Ezek a térségek az átmenet során súlyos helyzetbe kerültek. A korábbi városi gazdaságok fokozatosan erodálódtak, az azt működtető állami vállalatok leépültek, bezártak, vagy éppen kis cégekké alakulva vegetálnak. A külföldi és a hazai működő tőke ezeket a térségeket elkerüli, az ott élő, főként fiatal, még piacképes tudású népesség elköltözik, mivel kevés a helyi kitörési (közte a vállalkozási) lehetőség, ezért ezek a városok fokozatosan vesztik el a népességüket. Az országos átlaghoz képest magas az általános iskolát el nem végzettek aránya, az érettségivel és főként a diplomával rendelkezők aránya pedig alacsony. Az országos átlaghoz képest magas a munkanélküliség.

Az általunk elvégzett klaszterelemzés hasonló eredményeket hozott: ebben tematikus főkomponensek alapján történt a városok rangsorolása, mégpedig elsősorban a gazdasági tényezők alapján (ennek keretében a foglalkoztatottak, az adófizetők, a személyi jövedelemadó, a vállalkozások, a munkanélküliek, az inaktív keresők, az iparüzési adó, az egyéni vállalkozók száma került az elemzett tényezők körébe). Az iskolázottsági és a munkaerőpiaci helyzet két további szignifikáns tényezőnek bizonyult, ahol a vezető értelmiségiek arányát, a felsőfokú végezettséggel rendelkezők, a szellemi foglalkozásúak, a szolgáltatásban foglalkoztatottak adatait vizsgálták és rangsorolták (Rechnitzer, Berkes, Páthy 2016). Ez az elemzés szintén három nagy csoportot talált: az első csoportba a gazdasági teljesítményükben kiemelkedő új városok kerültek, így Paks, Tiszaújváros és Százhalombatta, ahol egy-egy nagyüzem alapozza meg a kedvező pozíciót. A második klasztert azok a városok alkotják, amelyekben a kilencvenes évek negatív trendjei megálltak. A vizsgálat szerint ezek Ajka, Várpalota és Oroszlány. A harmadik csoportot Komló és Ózd alkotta, mint a legkedvezőtlenebb mutatókkal rendelkező, komplex válsághelyzetü, a további leszakadás jeleit felmutató városok. A típusok megalkotásával kapcsolatban érdemes még egy megközelítést említeni, amely a versenyképességi rangsorokat vizsgálta. Ebben (az általunk vizsgált városok köréből) a legjobb helyzetbe Tatabánya és Dunaújváros, a legrosszabb pozícióba pedig Komló került (Barta 2014, 85.) 
A statisztikai mutatókra épített három, különböző fejlettségű új városcsoport társadalma az empirikus felvétel szerint is igen differenciált, és ez a differenciáltság kapcsolódik a statisztikai alapú fejlettségi szintekhez is: a fejlettebb városcsoportok esetében magasabb az iskolázottság szintje, magasabb a szellemi munkát végzők aránya, és nagyobbak a háztartási jövedelmek (s noha itt erről most nem volt szó, fiatalosabb a korszerkezet is).

$\mathrm{Az}$ 1. ábra egyértelműen mutatja, hogy a fejlett várostérségi csoportban az alacsonyan iskolázottak aránya jóval kisebb, mint a 11 újvárostérségben, és kisebb, mint a másik két városcsoport esetében. A legmagasabb végzettségűek jelenléte viszont számottevőbb a 11 elemü minta átlagához és a többi várostípushoz képest is. A foglalkozás szerinti megoszlásokból hasonló trend bontakozik ki: a 11 újvárostérségben - a fizikai alkalmazottak átlagos arányához viszonyítva - a fejlett városcsoportban a legalacsonyabb a fizikaiak aránya, a két másik városcsoportnál ezek az arányok nagyobbak. A háztartási jövedelmi megoszlásoknál sem találni eltéréseket az előzőekhez képest: a fejlett térségi csoportban a legalacsonyabb jövedelmi csoportok az átlagtól lefelé találhatók. A másik két esetben (kiváltképp a vesztes típusnál) az arány sokkal magasabb. A legmagasabb jövedelmi megoszlásokat nézve az látható, hogy a 11 új városi át-

1. ábra: A három, különböző fejlettségü újváros-térségcsoport társadalmi jellemzői

(a 11 újvárostérség átlagához viszonyítva) $(2015, \%)$

The social characteristics of three differently developed new town area compared to the overall, 11 new town area average $(2015, \%)$

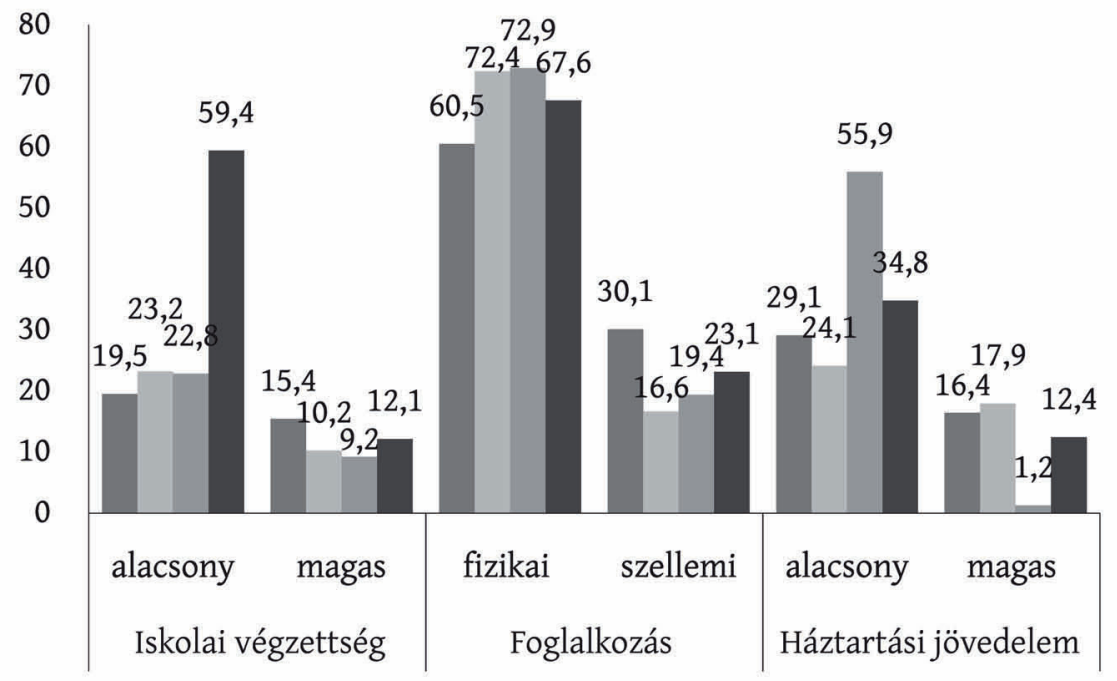

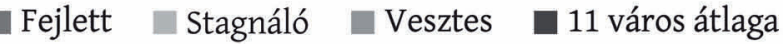


lagot leginkább (meglepő módon) a stagnáló egységben lévők adatai haladják meg, ezt követi a fejlett csoport aránya, a vesztesek típusában azonban ez a jövedelmi adat szinte nem is jelenik meg.

\section{A térbeli társadalmi elhelyezkedés sajátosságai}

A nemzetközi szakirodalom szerint a globális urbanizációban a területi társadalmi szerkezetekre az éles regionális egyenlőtlenségek kialakulása, a térbeli társadalmi polarizáció erősödése jellemző (Sassen 1991, 2000; Veltz 1996). A gazdagság és a felső társadalmi osztályok a városközpontokban és a vonzóbb elővárosokban, az alacsonyabb társadalmi osztályok részben a városközpontokban, részben a városkörnyéken koncentrálódnak. A térbeli társadalmi szegregáció erősödik a társadalmi kirekesztési folyamatok hatására is.

Az újvárosfejlesztések (főként első periódusai) tervezési, építészeti eszközökkel, később már csak ideológiai koncepciókkal törekedtek a szegregáció megakadályozására. A komplex városépítési szemlélet jegyében, egyben a szocialista realista stílusjegyek alapján épült első városnegyedek hosszú ideig a legvonzóbb városrészek voltak: az ekkor még viszonylag differenciált lakásszerkezethez kapcsolódva az ellátó intézmények is időben elkészültek, a zöldfelületek kiterjedtsége is megfelelő volt. A későbbi időszakok iparfejlesztési céljai, a népességszám növekedése, a tömeges lakásépítkezéseket megvalósító házgyári érdekek megbontották a korábbi komplex tervezési és építészeti elveket: az 1970-es évektől kezdve a többnyire négyszintes épületek mellé már magasabb (tízszintes) épületegyüttesek kerültek, miközben a (két-három szobás) lakások továbbra is standardizáltak voltak, a mindennapi élethez szükséges ellátó intézmények kialakítása pedig hiányzott. Az 1980-as évektől kezdve, de főként az 1990-es évek során - az ingatlan- és a lakáspiac magánosításának is tulajdoníthatóan - az új városok szinte mindegyikében az adott kornak megfelelö, modern lakónegyedek is épültek, amelyek a különböző társadalmi helyzetű népesség elvárásait, az új lakóhelyek iránti igényeit és piaci erejét is kifejezték.

Köztudott, hogy a szocialista urbanizáció ideológiai céljai szerint a keletés a közép-európai, közte a magyar új városok a munkások részére készültek, az ő érdekeik érvényesítését célozták. De már az 1970-es, 1980-as évek magyar kutatásaiból kiderültek az érdekérvényesítés anomáliái: a szocialista új városok az elit, a nagyvállalati (általában magasan képzett) műszaki és gazdasági menedzserek, a helyi tanácsi vezetők és a középszintű végzettséggel rendelkező szakmunkások és művezetők (főként férfiak) számára épültek. Az elitrétegek élet- és munkakörülményei, valamint jövedelmi helyzete, lakóhelyi viszonyai is sokkal kedvezőbbek voltak a helyi társadalmak más rétegeinek viszonyaihoz képest: a munkásrétegek, főként a segéd- és a betanított munkát végzők, az iskolázatlan női munkaerő, az értelmiségi munkát végzők, a diplomás rétegek 
hátrányokat szenvedtek (Mód, Kozák 1974; Szirmai 1988). A népesség különböző társadalmi csoportjai elkülönülten helyezkedtek el a térben is: a magasabb társadalmi státuszúak a kedvezőbb ökológiai pozíciójú és jobb lakásállományú negyedekben, míg az alacsonyabb társadalmi státuszú rétegek a kedvezőtlenebb helyzetű városrészekben (sokszor a korábban önálló falvakban) laktak (Haumont et al. 1999; Szirmai 1998).

Az 1989-1990-es rendszerváltás után tovább változtak a térbeli és társadalomszerkezeti jellemzők: a sikeresebb rendszerváltást lebonyolított új városokban a nagyvállalatok privatizációjának, a gazdaság diverzifikációjának (a korábbi nehézipari funkciók mellett új gazdasági szerepkörök kialakulása), az ingatlanpiacnak és a helyi várostervezés és -fejlesztés kibontakozásának köszönhetően. A globális hatások helyi érvényesülésének, főleg a multinacionális cégek beruházásainak következtében új társadalmi csoportok jelentek meg a helyi struktúrákban: az új külföldi tulajdonosok és menedzserek, a külföldi és magyar ingatlanfejlesztők, az önálló vállalkozók. Mindez részben helyi elitváltással is együtt járt, az újonnan megjelent társadalmi csoportok maguk mögé utasították a korábban nagyhatalmú állami nagyvállalati elit tagjait, és a helyi állami, önkormányzati vezetőket is. A jövedelmi és életminőségolló nőtt, főként a külföldi és a hazai tulajdonosok, a külföldi és a hazai menedzserek, továbbá a képzett szakmunkások és a betanított, valamint segédmunkások között. A lakóhelyi diverzifikáció is módosult, illetve erősödött: a történetileg kialakult szegregációs sémák mellett új területi elkülönülési formák jelentek meg. A 2015-ben végzett kutatás szerint, amely az új városi térségek társadalmi szerkezetét vizsgálta, szignifikáns társadalmi polarizáció jött létre a városok belső negyedeiben élők, illetve - infrastrukturálisan és egyéb objektív mutatók alapján különbözöképpen fejlett - városkörnyékek ${ }^{6}$ lakossági csoportjainak társadalmi összetétele között (2. és 3. ábra). ${ }^{7}$

2. ábra: A lakosság megoszlása iskolai végzettség szerint az új városokban - részletes övezeti besorolás alapján $(2015, \%)$

Distribution of new town population according to educational level and organized by regional categories $(2015, \%)$

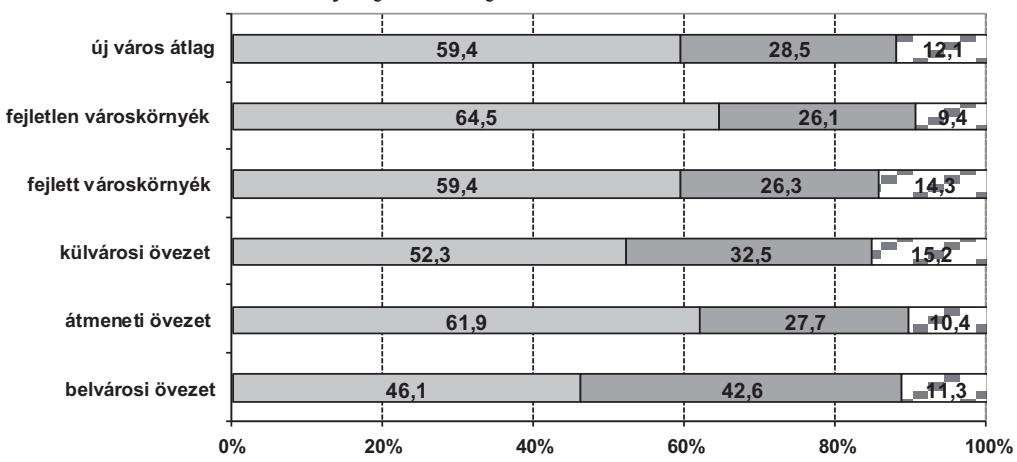

$\square$ alapfokú + érettségi nélküli középfok 
3. ábra: A lakosság megoszlása foglalkozási csoportok szerint az új városokban - részletes övezeti besorolás alapján (2015, \%)

Distribution of new town population according to employment groups and organized by regional categories $(2015, \%)$

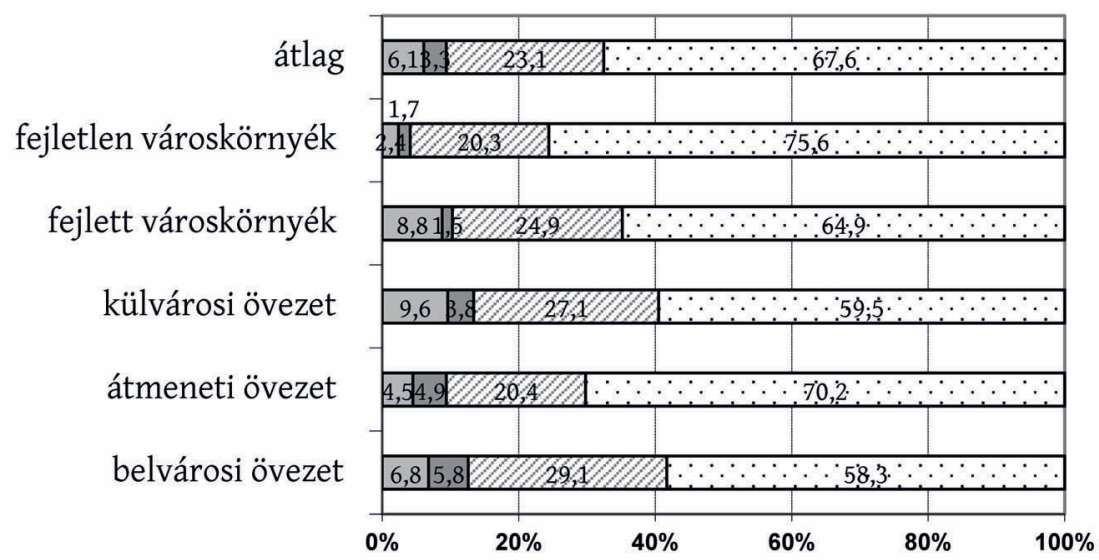

vállalkozó $\square$ alkalmazott vezető $\square$ szellemi alkalmazott $\square$ fizikai alkalmazott

A fenti ábrákból jól látszanak a belső társadalmi megosztottságok: a belvárosok társadalmára a közepesen képzett rétegek magasabb arányai a jellemzöek, a mintabeli átlaghoz képest a középfokú végzettségüek, az érettségivel rendelkezők koncentrációja magas, miközben az alapfokú végzettségűek jelenléte alacsonyabb. A diplomások aránya átlagos (11,3\%). A foglalkozási megoszlások hasonló trendet mutatnak: a szellemi alkalmazottak arányai magasabbak a fizikai alkalmazottak itt jellemző arányainál (az alkalmazott vezetők helyi arányai szintén magasabbak a minta átlaghoz képest). A városi centrumokból kifelé haladva az átmeneti övezetek társadalmai kissé eltérőek: a képzettebb csoportok (közte a fizikai dolgozók) arányai alacsonyabbak, az alacsonyabb végzettségüek és a fizikai alkalmazottak arányai magasabbak. A diplomások mindkét övezetben alulreprezentáltak. Ők, de a vállalkozó rétegek is, a következő városi egységben, a külvárosi övezetekben vannak az átlaghoz képest magasabb arányokban jelen, itt az alacsonyabb végzettségűek (és a fizikai dolgozók) arányai is kisebbek. A fejlett városkörnyéki településeken a mintabeli átlagokhoz képest magasabb a szakképzettebb és iskolázottabb csoportok aránya, míg a fejletlenebb településeken alacsonyabb. Fontos trend, hogy a külvárosi övezetek és a fejlett városkörnyékek esetében nagyon hasonló a diplomások aránya: a 12,1\% diplomás átlaghoz képest a külvárosokban 15,2\%, a fejlett városkörnyéken pedig 14,3\% az arányuk.

A 2015-ben végzett kutatásban nemcsak a 11 új városi térre jellemző társadalmi polarizációs trend bontakozott ki, hanem a statisztikai adatelemzésekkel feltárt három különböző fejlettségü új városcsoport szerinti térbeli társadalmi polarizációs folyamatok is nyilvánvalóvá váltak. Amikor a három városcsoport belső területi megoszlásait elemeztem - az iskolázottsági és fog- 
lalkozásszerkezeti, valamint a háztartási jövedelem, a kor és a lakóhely-változtatási szándékok szerint - lényeges különbségeket találtam, részben a 11 új városi térségben mérthez képest, részben pedig a különböző fejlettségü városcsoportok között. A terjedelmi korlátok miatt csak az első két tényező elemzését mutatom be.

A fejlettebb várostérségi csoportok belvárosaiban élő diplomások aránya jóval alacsonyabb (7,0\%) a csoportátlaghoz (15,4\%), de a 11 város átlagához (12,1\%) képest is. A legalacsonyabb végzettségűek aránya (9,3\%) szintén alacsonyabb, mint a csoportátlag (19,5\%), és sokkal alacsonyabb, mint a 11 elemű városátlag $(59,4 \%)$. A szellemi alkalmazottak belvárosi aránya szintén alacsonyabb (20,5\%), mint a csoportátlag (30,1\%), és alacsonyabb, mint a 11 új városi átlag (23,1\%). A vállalkozók belvárosi aránya (2,6\%) jóval elmarad a csoportátlaghoz $(7,12 \%)$, de a 11 város átlagához (6,1\%) képest is. A fejlettebb városcsoport képzettebb (de egyben magasabb jövedelmű) csoportjai, a diplomások már kevésbé belvárosiak, inkább a külvárosokban $(21,5 \%)$ és a fejlett városkörnyéki övezetekben $(17,9 \%)$ találni őket jóval nagyobb arányban, mint amennyi a fejlett városcsoportbeli átlaguk (15,4\%), és mint a 11 új városi átlag $(12,1 \%)$. Vélhetően ezekben a városokban a képzettebb vállalkozói csoportoknak módjuk volt a városokon belül mozogni, és a külvárosi övezetekbe vagy a fejlettebb környéki településekre költözni. Valószínűleg a korábban itt élő, alacsonyan képzett rétegek tagjai közül is sokan kifelé mozdultak, de nyilván máshová, mint a diplomások.

A fejlett városcsoport típusában is differenciáltak a fejlett és a fejletlen városkörnyékek: a diplomások aránya jelentősen eltérő: a 15,4\%-os csoportátlaghoz (de a 12,1\%-os újvárosi átlaghoz) képest föként a fejlett környéken magas a jelenlétük: 17,9\%; a fejletlen környékbeli térségekben csak kisebb arányban $(12,8 \%)$ élnek. A többi iskolázottsági kategória esetében nincs szignifikáns eltérés, bár az érettségizettek aránya a fejlettebb térségekben magasabb. A foglalkozási megoszlásoknál jellemzőbbek a differenciák: a fejlett környékeken a csoportátlaghoz (60,6\%) képest jóval alacsonyabb a fizikaiak aránya: 55,2\%, a fejletlen esetekben ez az arány 68,6\%. A másik lényeges eltérést a vállalkozóknál látni: a fejlett környéki esetekben a 7,1\%-es városcsoportátlagot meghaladó mértékben, 10,5\%-ban találni helyi vállalkozói réteget. A másik, fejletlen környék típusánál ez az arány jóval kisebb: 2,3\%. Ebben a várostérségi csoportban, a külvárosokban és a fejlett környékeken élő diplomások arányában nincs olyan arányú hasonlóság, mint amelyet a 11 városra vonatkozó megoszlásokban lehetett tapasztalni. A 15,4\%-os fejlett csoportátlaghoz képest a külvárosi övezetekben jóval magasabb, 21,5\% a diplomások aránya, a fejlett városkörnyék esetében ez az arány $17,9 \%$.

A stagnáló városcsoport esetében, a 11 városi térre jellemző trend szerint a belvárosok társadalmi státuszai kedvezőek - annak a diplomás aránynak (15\%) tulajdoníthatóan, amely mind a stagnáló új városi csoportbeli átlaghoz (10,2\%), mind pedig a 11 új városi átlaghoz $(11,2 \%)$ képest is magasabb. Az érettségizettek helyi aránya is magasabb (47,5\%), mint a stagnáló csoportbeli $(29,8 \%)$ átlag 
és mint a 11 város átlaga $(28,5 \%)$. A legalacsonyabb végzettségűek belvárosi aránya $(17,5 \%)$ is alacsonyabb, mint a csoportátlag $(23,2 \%)$ és jóval alacsonyabb, mint a 11 elemü városátlag $(59,4 \%)$.

A szellemi alkalmazottak arányai is kiemelkedőek: a 16,6\%-os csoportátlaghoz képest itt 34,3 \%-ban vannak jelen, s ez a 11 új városi átlaghoz $(23,1 \%)$ viszonyítva is magas. A 6,6\%-os csoportátlaghoz képest a vállalkozók arányai is magasabbak (8,6\%). Az átmeneti övezetek társadalmi összetétele átlagos. A külváros pozíciói itt is jobbak, de nem a diplomások helyi arányai miatt (az szinte átlagos, $11,4 \%)$, hanem az érettségizettek magasabb részaránya (37,4\%), illetve az alacsonyan iskolázottak átlaghoz $(23,2 \%)$ viszonyítva jóval kisebb helyi aránya miatt $(17,9 \%)$.

A stagnáló városi csoport esetében a fejlett és a fejletlen városkörnyék diplomásainak arányaiban (9,5\% és 8,5\%) nem látni számottevő különbséget: az mindkét esetben lefelé tér el a csoportátlagtól (10,2\%) és a 11 város átlagától is $(12,1 \%)$. A fizikai dolgozók aránya (a 72,4\%-os csoportátlaghoz és a 11 új város 67,6\%-os átlagához viszonyítva) a fejletlen környéken jóval magasabb (81,1\%). A vállalkozók is a fejlettebb térségeken vannak valamivel többen (az átlag 6,6\%, a helyi arány 7,2\%). Ebben a városcsoportban sem tapasztalható közeledés a külvárosok és a fejlett térségi övezetek iskolázottsági összetétele között.

A vesztes városcsoport esetében szintén az a helyzet, hogy a belvárosok társadalmi státuszai az átlaghoz képest kedvezőbbek, a diplomások helyi aránya $(12,5 \%)$ magasabb, mint a csoportátlag $(9,2 \%)$, de nem tér el a 11 város átlagától. Az adott városi csoportban átlagosan $25,4 \%$-os érettségizettek arányához képest igen magas a helyi arány, $46,9 \%$. Ez a 11 város átlagánál (28,5\%) is számottevőbb. A foglalkozási szerkezetben a fizikai alkalmazottak belvárosi aránya jóval alacsonyabb $(55,2 \%)$ a csoport átlagához és a 11 városátlaghoz képest is (67,6\%). Fontos megemlíteni az átlaghoz (4,1\%) képest jóval magasabb (10,3\%) vállalkozói arányt. Az átmeneti övezetek társadalmi összetétele már kedvezőtlenebb. A külváros pozíciói itt is kedvezőbbek: a 9,2\% diplomás átlaghoz képest 11,9\% a helyi arány, az alacsonyabban képzettek aránya is alacsonyabb. A vesztes városcsoport fejlett és fejletlen környékbeli területei esetében jellemző a diplomások arányában lévő eltérés: a fejlettebb környékeken (a 9,2\%-os átlaghoz képest) valamivel magasabb a diplomások aránya (9,9\%), ezzel szemben a fejletlenebb esetekben jóval alacsonyabb a diplomások jelenléte (6,1\%). A többi iskolázottsági szint esetében alig látni jellemző eltérést a kétféle térség között. A fizikai arányok egy kicsit magasabbak a fejletlen városi környékeken, itt a vállalkozók is kevesebben vannak (1,4\%, a 4,6\%-os átlaghoz viszonyítva). Ezzel szemben a fejlettebb környékeken a vállalkozói arány 6,5\%. A külvárosok és a fejlett térségi övezetek közötti közeledést itt sem tapasztalni.

Az elemzések azt mutatják tehát, hogy a 11 új várostérség és a fejlett új várostérségcsoport területi társadalmi trendjei egyeznek meg leginkább. A hasonló trendek okai: a magasabb társadalmi státuszú (magasabban iskolázott és képzettebb) csoportok korlátozottabb belvárosi arányai, az átmeneti övezetek 
leromlott társadalmi összetétele, valamint a városkörnyéki települések diverzifikációja és a fejlettebb városkörnyéki településeknek a fejletlenebbekhez képest jóval kedvezőbb társadalmi szerkezete. A stagnáló és a vesztes új várostérségcsoport trendjei annyiban különböznek ettől, hogy a magasabb társadalmi státuszú (magasabban iskolázott és képzettebb) csoportok nagyobb számban élnek a belvárosokban, de a külvárosokban szintén megtalálhatóak. Az átmeneti övezetek társadalmi összetételének leromlása itt is tapasztalható, ahogy a városkörnyéki települések diverzifikációja is: a fejlettebb városkörnyéki településeknek a fejletlenebbekhez képest kedvezőbb a társadalmi szerkezete.

\section{Összegzés: az európai várostrendek felé}

Az elemzések egyértelművé tették, hogy - a történeti adottságok és főként az 1990-es évek óta tartó rendszerváltozás folyamataiban az átmenetet meghatározó globális és történeti mechanizmusok szövevényeként - a magyar településhálózatban eddig nem, vagy csak kisebb mértékben megnyilvánuló térbeli társadalmi egyenlőtlenségi forma jött létre: az új városok közötti térbeli társadalmi egyenlőtlenségek rendszere. Ezt a rendszert, megkésve, ugyanazok az erők hozták létre, mint a fejlett ipari országokban az 1970-es évek után. A gazdaság átstrukturálódása, a globális gazdaság térhódítása folytán a társadalmi és gazdasági egyenlőtlenségek már nemcsak a városok belső viszonyaiban éleződtek, hanem a különböző városi típusok között is (Kleniewski 2004, 9).

A különböző vizsgálatok bizonyították, hogy a posztszocialista új városok és azok térségei korántsem jelentenek homogén közeget: a különböző társadalomstatisztikai és szociológiai jellemzőik, társadalmi összetételük, és térbeli elhelyezkedésük differenciáltsága alapján különböző fejlettségi egységekből állnak. A fejlettebb jellemzőkkel rendelkező új városi csoportok sokkal inkább alkalmazkodnak a globális világhoz, az általunk vizsgált dimenziókban jobban integrálódnak az európai városrendszerekhez is, mint a stagnáló és a vesztes várostérségi csoportok.

Az integrálódást támogatták a kedvező regionális és földrajzi (egyben közlekedési) pozíciók, a nagyobb városokhoz (főleg Budapesthez) való térbeli közelség, a globális hatásokkal (és tőkével) való érintettség, a nemzetközi szinten is prosperáló (többnyire energetikai szektorokban müködő) nagyipari gazdaság, az innovatív helyi vezetés és a globális tőke működtetése számára szükséges szakképzett, iskolázott munkaerő. E fejlettnek nevezett városcsoportokban tapasztalhatók az európai várostípusokhoz való közeledés jelei.

Az integrálódást akadályozta a globális hatások hiánya vagy korlátozott érvényesülése; az elszigetelt, városhiányos földrajzi helyzetek; a nemzetközi globális piacon müködésképtelenné vált városgazdaságok; az innovatív helyi vezetés hiánya, valamint a kedvezőtlenebb társadalmi és közösségi viszonyok. E stagnálóknak és veszteseknek nevezhető új várostérségi típusok esetében mu- 
tatkoznak az európai várostípusoktól való eltérések jelei, és egyben a szocialista történeti viszonyok még mindig érvényesülő hatásai.

$\mathrm{Az}$ integráció trendjeit, mégpedig a globális urbanizáció érvényesülését mutatják az újvárostérségekben élők társadalmi elhelyezkedési folyamatai is. A 11 újvárostérségben, illetve a fejlett újvárostérségek csoportjában élő népesség társadalmi elhelyezkedése, megkésve ugyan, de követi a globális urbanizáció második - dekoncentrációban megnyilvánuló - szakaszát. Ebben a szakaszban, a globális európai trendeknek megfelelően, az új városokban is átalakul a belső városrészek értéke: az alacsonyabb jövedelműek számára az itt megdrágult lakás- és ingatlanárak miatt, a magasabb státuszú népesség számára a belső negyedek lakótelepi környezetének elutasítása és az egyedi tervezésű vagy családi házas övezetek iránti lakásigények miatt. Megindulnak a belső (a belvárosból a város egyéb belső negyedei felé irányuló) mozgások és a városkörnyékeket megcélzó szuburbanizációs folyamatok is. A különböző társadalmi pozíciójú rétegek differenciált lakóhelyválasztási stratégiái, illetve lakáspiaci helyzete a városkörnyék diverzifikációjához vezet. A másik két fejletlenebb városcsoport esetében ez a folyamat még nem indult meg, a város belső részei még megtartották a magasabb társadalmi státuszú lakosaikat, de a kiköltözések várhatóan fel fognak gyorsulni. Ezt már jelzik a költözési törekvések, amelyek ugyan a 11 új városi térségben sem magasak (a megkérdezettek 6\%-a állította, hogy el fog költözni, 11\% pedig elköltözne, de nincs rá lehetősége), de a különböző fejlettségü városcsoportokban élők esetében ebben árnyalt különbségek vannak. A vesztes településeken lakók költözési törekvései a legnagyobbak, az átlagot is meghaladók (8,7\% állította, hogy el fog költözni, 16,5\% pedig elköltözne, ha lenne rá lehetősége). A fejlett új városi csoportban élők szeretnének az átlaghoz képest kisebb arányban elköltözni (5\%), és ők válaszolták kisebb arányban (6,9\%), hogy elköltöznének, de nincs rá lehetőségük. A stagnáló új városok lakói hasonló arányt jelöltek meg (4,9\%) a biztos költözés esetében.

A globális városfejlődési trendek újvárostérségi kibontakozását egy másik térbeli társadalmi trend is sejteti: meglepő hasonlóságot látni a 2015-ös, 11 új városi térségben (egyszersmind a fejlett új városi csoportban) élők térbeli társadalmi szerkezete és a 2014-es magyar nagyvárostérségi népesség társadalmi megoszlásai között. Mindkét esetben a legmagasabb társadalmi státuszúak (a diplomások, a szellemi munkát végzők, a legmagasabb jövedelemmel rendelkezők) egyre nagyobb teret foglaltak el a belső városrészekben, de a külső városi negyedekben is növekedett az arányuk, a fejlett és a fejletlen városkörnyékek magasabb társadalmi státuszú népessége közötti korábbi aránykülönbség pedig csökkent vagy eltűnt. A magasabb társadalmi státuszúak mintegy „kiszorították” az alacsonyabb társadalmi státuszcsoportokat a belső városi terekből, illetve benyomultak a fejletlenebb városkörnyékekre. Tették ezt többek között azért is, mert a városból elvágyódó fiatalabb, alsó középosztálybeli rétegek könnyebben találtak olcsóbb lakásokat, ingatlanokat a fejletlenebb (egyben kedvező táji adottságú) környékbeli településeken. 
Mindez pedig az európai városfejlődési trendeknek is megfelel (Csizmady, Ferencz 2016; Szirmai 2009; Szirmai, Ferencz 2015).

A magyar új városi térségek társadalmi jellemzői tehát közelítenek - de igen nagy különbségekkel - a globális, illetve a nyugat-európai trendekhez: a gazdaságilag, infrastrukturálisan és társadalmilag fejlettebb új városi térségek integrációja előrehaladottabb, a fejletlenebb új városi térségek integrációja késleltetett.

\section{Jegyzetek}

1 A globális urbanizáció szakaszai: a városrobbanás, a viszonylagos dekoncentráció, a dezurbanizáció és a globalizált urbanizáció (Enyedi 2011).

2 A projekt címe: Egy új városfejlődési modell szerveződése? Átmenet és globalizáció a magyarországi új városokban és térségeikben. A megvalósítás intézményi kereteit az MTA TK Szociológiai Kutatóintézet biztosította. A projekt szerződésszáma: OTKA K 81547. A kutatást Szirmai Viktória vezette. A megvalósításban részt vettek: Baranyai N., Csizmady A., Halász L., Laki I., Szirmai V., Uzzoli A., Váradi Zs.

3 A megvalósítás intézményi kereteit az MTA Társadalomtudományi Kutatóközpont Szociológiai Intézete adta. Az OTKA által finanszírozott projekt szerződésszáma: K 106169. A kutatást Szirmai Viktória vezette. A project megvalósításában részt vettek: Baranyai N., Berkes J., Berki M., Csizmady A., Ferencz Z., Gajdoš P., Halász L., Hajda D. M., Kissfazekas K., Moravanská, K., Páthy Á., Rechnitzer J., Schuchmann J., Szirmai V., Węcławowicz, G.

4 A mélyinterjús elemzési módszerekkel vizsgált magyar terepek Tatabánya, Dunaújváros, Komló, valamint Kazincbarcika és térségeik voltak, továbbá egy lengyel (Tychy) és egy szlovák új városi térség (Nova Dubnica). A 11 magyar új városra és környékére a reprezentatív vizsgálat módszere: kérdőíves kutatás: 2275 fős, kor, nem, iskolai végzettség és településszerkezet szerinti reprezentatív minta alapján. Az adatfelvételre 2014. november 25. és 2015. január 29. között került sor. Pénzügyi okok miatt csak a magyar új városok reprezentatív felvételére volt mód, a másik két ország új városait csak esettanulmányok formájában vizsgáltuk.

5 A két projekt a következő volt: A várostérségek, térbeli társadalmi egyenlőtlenségek és konfliktusok - az európai versenyképesség térségi társadalmi tényezői című kutatási projekt 2004 és 2007 között valósult meg, konzorciumi keretben, a Nemzeti Kutatási Fejlesztési Programok támogatásával (nyilvántartási szám: 5/083/2004.), a konzorciumvezető intézmény az MTA Szociológiai Kutatóintézet volt, a kutatást Szirmai Viktória vezette. Az eredményekrőll lásd Szirmai (2009). A másik projekt címe A társadalmi konfliktusok - társadalmi jól-lét és biztonság - versenyképesség és társadalmi fejlődés (TÁMOP-4.2.2.A-11/1/KONV-2012-0069). Ez az Európai Unió támogatásával, az Európai Szociális Alap társfinanszírozásával valósult meg, konzorciumi keretben, a Kodolányi János Főiskola irányításával, 2013 és 2015 között, a kutatást Szirmai Viktória vezette. A vonatkozó eredményeket lásd részletesen: Szirmai (2015).

6 A városkörnyéki településeket rangszámmódszerrel tipizáltuk, illetve választottuk ki: ennek során a megközelíthetőség, a lakáshelyzet, a köz- és felsőoktatás, az egészségügyi ellátás, a vállalkozói aktivitás, az adózás, a jövedelmek, a foglalkoztatás, a munkanélküliség, a mobilitás, a szociális ellátás szempontjait vettük figyelembe. Az így elkészült mutatók összesítéséből kaptuk meg azt a fejlettségi rangsort, amely alapján a három legfejlettebb és a három legfejletlenebb települést kiválasztottuk és elemeztük. Ezt a módszert alkalmaztuk a nagyvárosi és az újvárostérségi kutatásokban is.

7 A 2. és a 3. ábra elkészítésében Ferencz Zoltán volt a segítségemre, ezt ezúton is köszönöm. Egyúttal köszönöm a tanulmány két anonim opponensének a segítségét, hasznos tanácsaikat is. 


\section{Irodalom}

Barta Gy. (2002): A magyar ipar területi folyamatai 1945-2000. Dialóg Campus Kiadó, Budapest, Pécs

Barta Gy. (2014): Szocialista városok - Városok a szocializmusban. In: Berki M., Halász L. (szerk.): A társadalom terei, a tér társadalma. Art Webber Stúdió, Budapest, 75-99.

Brevet, N. (2011): Le(s) Bassin(s) de Vie de Marne-La-Vallée. L'Harmattan, Paris

Le Corbusier (1923): Vers une architecture. G. Cres, Paris

Csizmady A. (2013): Új városok - régi városok: Összehasonlító elemzés. In: Szirmai V. (szerk.): Csinált városok a XXI. század elején. MTA TK, Budapest, 215-251.

Csizmady A., Ferencz Z. (2016): Social polarization mechanisms in the Hungarian new town regions. In: Szirmai, V. (ed.): "Artificial towns" in the 21st century. Social polarisation in the new town regions of East-Central Europe. Institute for Sociology, Centre for Social Sciences, Budapest, 315-341.

Enyedi Gy. (1996): Urbanization under socialism. In: Andrusz, G., Harloe, M., Szelényi, I. (eds.): Cities after socialism: Urban and regional change and conflicts in post-socialist societies. Blackwell, Oxford, 100-119. http://doi.org/dwd446

Enyedi Gy. (2011): The stages of urban growth. In: Szirmai, V. (ed.): Urban sprawl in Europe. Aula Kiadó, Budapest, 45-62.

Enyedi Gy. (2012): Városi világ. Akadémiai Kiadó, Budapest

Ferencz Z. (2015): Az új városok és környékük társadalmi, gazdasági helyzete. Kézirat. MTA TK SZI, Budapest

Haumont, N., Jalowiecki, B., Munro, M., Szirmai, V. (1999): Villes nouvelles et villes traditionnelles: Une comparaison internationale. L'Harmattan, Paris

Horváth Gy., Rechnitzer J. (szerk.) (2000): Magyarország területi szerkezete és folyamatai az ezredfordulón. MTA RKK, Pécs

Howard, E. (1898): Garden cities of tomorrow. Sonnenschein \& Co., London

Izsák É. (2003): A városfejlödés természeti és társadalmi tényezői: Budapest és környéke. Napvilág Kiadó, Budapest

Kleniewski, N. (ed.) (2004): Cities and society. Wiley-Blackwell, Malden

Mód A.-né, Kozák Gy. (1974): A munkások rétegződése, munkája, ismeretei és az üzemi demokrácia a Dunai Vasmü két gyárrészlegében. Akadémiai Kiadó, Budapest

Musil J. (2005): City development in Central and Eastern Europe before 1990: Historical context and socialist legacies. In: Hamilton, I., Andrews, K. D., Pilcher-Milanovic, N. (eds.): Transformation of cities in Central and Eastern Europe toward globalisation. United Nations University Press, 22-44.

Nemes Nagy J. (2005): Fordulatra várva - a regionális egyenlötlenségek hullámai. In: Dövényi Z., Schweitzer F. (szerk.): A földrajz dimenziói. MTA FKI, Budapest, 141-158.

Provoost, M. (2010): New towns for the 21st century. The planned vs. the unplanned city. SUN International New Town Institute, Amsterdam

Rechnitzer J. (2002): A városhálózat az átmenetben, a kilencvenes évek változási irányai. Tér és Társadalom, 3., 165-183.

Rechnitzer, J., Berkes, J., Páthy, Á. (2016): The "post-socialist” towns in the Hungarian city network. In: Szirmai, V. (ed.): "Artificial towns" in the 21st century. Social polarisation in the new town regions of East-Central Europe. Institute for Sociology Centre for Social Sciences, Budapest, 341-371.

Sassen, S. (1991): The global city, New York, London, Tokyo. Princeton University Press, New Jersey

Sassen, S. (2000): New frontiers facing urban sociology at the millennium. British Journal of Sociology, 1., 143-161. http://doi.org/fs37fz

Szelényi, I. (1996): Cities under socialism and after. In: Andrusz, G., Harloe, M., Szelényi, I. (1996): Cities after socialism, urban and regional change and conflict in post-socialist societies. Blackwell, Oxford, 286-318.

Szirmai V. (1988): „Csinált” városok. Magvető Kiadó, Budapest

Szirmai, V. (1998): "Socialist" cities (new towns) in the post-socialist era. In: Enyedi, Gy. (ed.): Social change and urban restructuring in Central Europe. Akadémiai Kiadó, Budapest, 169-189.

Szirmai V. (2009): A centrum-periféria modell átalakulása. In: Szirmai V. (szerk.): A várostérségi versenyképesség társadalmi tényezői. Dialóg Campus Kiadó, Budapest, Pécs, 119-123. 
Szirmai V. (szerk.) (2013): Csinált városok a XXI. század elején. MTA TK, Budapest

Szirmai V., Ferencz Z. (2015): A magyar nagyváros-térségek térbeli-társadalmi jellegzetességei, a centrum-periféria modell átalakulása. In: Szirmai V. (szerk.): A területi egyenlőtlenségektól a társadalmi jól-lét felé. KJF, Székesfehérvár, 147-167.

Szirmai, V. (ed.) (2016): "Artificial towns" in the 21st century. Social polarisation in the new town regions of East-Central Europe. Institute for Sociology, Centre for Social Sciences, Budapest

Uzzoli A. (2013): Az új városok kialakulása. In: Szirmai V. (szerk.): Csinált városok a XXI. század elején. MTA TK, Budapest, 35-53.

Veltz, P. (1996): Mondialisation des villes et territoires. L'économe d'archipel, Économie en liberté. Presses Universitaires de France

http://www.tradingeconomics.com (Letöltés: 2017. július 31.) 